\title{
Analysis of Loan Acquisition and Repayment among Small Scale Rice Farmers in Ebonyi State, Nigeria: Implication for Effective Credit Delivery.
}

\author{
Mgbebu, Ezekiel Sunday ${ }^{1}$, Achike, Ifeyinwa Anthonia ${ }^{2}$ \\ Department of Agricultural Economics, University of Nigeria, Nsukka
}

\begin{abstract}
Loan acquisition and repayment among small scale rice farmers in Ebonyi State, Nigeria was investigated. The study determined the quantum of loan sourced and acquired by small scale rice farmers; ascertained the determinants of successful loan acquisition from formal financial institutions; estimated the repayment rates among the beneficiaries; and analyzed factors that affect loan repayment performance of the beneficiaries. A multistage simple random sampling technique was adopted in the selection of the respondents. Primary data were generated through the use of well structured questionnaire admitted to 120 small scale rice farmer beneficiaries. Descriptive statistics, multiple regression and logit regression model were employed in data analysis. Analysis revealed that each of the farmers applied for an average amount of $\$ 170,173.40$ but was able to procure an average amount of $\$ 128,557.40$. Furthermore, multiple regression result indicated that farm size, cost of farm inputs and interest charge were significant in determining loan acquisition. An average of $28 \%$ of respondents defaulted in loan repayment. The logit regression indicated that farming experience, income, interest charge, loan application cost, loan size, security and number of installments were found to have played significant role in loan repayment performance. The study therefore, recommended that a sustainable credit policy framework be established by relevant agencies to enable farmers access adequate loan amount at reduced interest rate and also on time from formal financial institutions.
\end{abstract}

\section{Introduction}

Agricultural sector is situated within the framework of the rural economy and financial markets. A key feature of the sector is the dominance of the small holding farm families or rural households. The pivotal role of these small holding farm families as an engine of industrial growth and development of Nigeria's economy cannot be over-emphasized. The agricultural sector plays a pertinent role in Nigeria economy contributing about $40 \%$ of gross domestic products (GDP) and employing about $65 \%$ of the workforce in the country (Ezeugo, 1998; Olomola, 2006).

However, there has been a marked reduction in the performance of Nigeria's agriculture and consequently, its contribution to the gross domestic product (GDP). The decline in the contribution of the sector to the Nigeria's economy is attributable to several factors among which are negligence on the part of government, lack of formal national credit policy and ineffective credit institutions. Credit is a major component of financial services needed in all production levels, marketing and product servicing. Improving access to finance is an important aspect of fostering development in the rice sub-sector. Studies have indicated that loans are essential tools for the adoption of modern practices in agriculture. The need for credit is further stressed by the fact that the bulk of the farmers in the study group produce small marketable surpluses that they can hardly save from their earnings to take advantage of improved technologies and opportunities in the market.

In fact, difficulties in credit procurement have also been confirmed by various authors (Nwagbo, 1993; Nto and Mbanasor, 2008, Okorie, 1998; Olaitan, 2005). This difficulty in credit procurement according to lawal and Shittu (2006) causes setback to the productivity of farmers as a result of the fact that, small scale rice farmers do not have the resources to procure improved seedlings, chemicals and hired labours, as well as transport and markets for their produce which would have improved their productivity and welfare.

In Nigeria, agriculture is not practiced in a purposeful and enterprising manner. Many farmers engage in agriculture at subsistence level rather than at commercial level. This may be due to low output, low income, low savings which result to low investment including lack of collateral for accessing credit. These make farmers unable to accumulate capital goods required for purposeful and sustainable agribusiness ventures, causing their level of capital utilization to be very low. To achieve a total transformation of small holder agriculture from subsistence orientation to market orientation requires the availability of adequate credit or loan. 


\section{Problem Statement}

Preliminary observation shows that most innovations in agriculture inevitably increase the capital requirements of farmers. Improving access to finance is an important aspect of fostering development in rice sub-sector. Relevant literatures have confirmed that agriculture in Nigeria and many developing countries is constrained by lack of credit.

According to Ogah, et al, (2015), Credit accessibility and utilization is influenced by farmers' socioeconomic characteristics, the challenges of covering long distance to the bank, insistence on provision of collateral, inadequate credit granted, unwillingness of bank in granting agricultural credit, high rate of interest charged by private money lenders, delay and difficulty in communication with bank officials in acquiring credit. Farmers, especially small holder farmers are faced with different problems among which is the inadequate or restricted access to capital and limited access to credit facilities. Adegbite, Momoh and Alade (2007) noted that credit is required to break the vicious cycle of low productivity. Therefore, farm credit remains one of the major means of improving farm capital investment.

Without credit, most small scale rice farmers have little chance of substantially increasing their production. This brings to the fore, the importance of poverty among the farming population as a factor in an organization of agricultural credit. Often this factor is not fully acknowledged. Poverty is of direct significance because technological improvement must often be adopted with more capital investments, and when incomes are low, such risks appear to be great. The relatively low level of farm income has restricted the operations of the small scale rice formers to small enterprises. This establishes the vicious cycle whereby farmers always remain small producers and relatively poor. The small holder rice farmers in Ebonyi State have moderate resources for their activities irrespective of her position as one of the rice producing states in Nigeria and therefore need production credit from formal financial institutions to break the vicious cycle of low income and poverty. This therefore, underscores the need for more realistic and determined efforts to modernize the rice sub-sector through extension of easy credit facilities to the farmers in this study group. Consequently, lead to the transformation of their smallholdings to modern commercial concerns with increased capacity of the farmer beneficiaries to enhance their repayment performance.

\section{Objectives Of The Study}

The broad objective of this study was to empirically analyze loan acquisition and repayment among small scale rice farmers in Ebonyi State, Nigeria. Specifically, the study sought to:

i. determine the amount of loan sourced and acquired from various formal lending agencies;

ii. ascertain the determinants of loan acquisition from formal financial institutions by small scale rice farmers;

iii. estimate the repayment performance among beneficiaries; and

iv. analyze factors that affect loan repayment performance of the beneficiaries;

\section{Empirical Literature Review}

A number of factors explain why small scale farmers' access to credit is sometimes limited. Ukoha et al (2011) remarked that farmers' demand for credit is governed by socio-economic and environmental factors. These factors, they defined as the subsistence nature of production, land tenure problems, technological stagnation, and lack of restructured market outlets, social organizations, attitude and values.

However, Ike and Abojei (2009) found that the volume of credit or degree of indebtedness depended upon the age, sex, crop hectrage, farm size, farmers' income, input cost, production pattern and form of land tenure. Hussien (2007) indicated that farm households are more likely to prefer the informal sector to the formal sector with respect to flexibility in rescheduling loan repayments in times of unexpected income shocks. Doan et al (2010) found that the likelihood of credit constraints increases with distance to the nearest banks, which suggests that supply-side interventions could help in overcoming credit constraints. Okurut (2001) also found that the location of the financial service providers and their conditions greatly influence the probability of access. Komicha (2007) found that farm households are discouraged to borrow from the credit sector if it is located farther away. This is due to the monetary costs of transaction incurred, especially transportation cost, which increase with lender-borrower distance and in turn raises the effective cost of borrowing at otherwise relatively lower interest rate in the sector.

Amjad and Hasnu (2007) found the tenure status, family labor, literacy status, off-farm income, value of non-fixed assets and infrastructure quality to be the most important variables in determining access to formal credit. They also found that the total operated area, family labor, literacy status and off-farm income are significantly related to the determination of credit status of smallholder farmers from informal sources. Land tenure status was found to be the single most important variable determining credit status.

On the other hand, Oboh and Ekpebu (2010) found that farmer's age, educational level, farm size and household size, length of loan delay and visitation by bank officials significantly affected the rate of credit allocation to farmers. Duy $(2011,2012)$ in a study in Vietnam, found that access to credit was positively related 
to a larger family with relatively more dependants and that households with larger landholding had a higher probability of borrowing. The study also found that personal characteristics such as level of education, marital status and involvement in village work were important factors. Higher educated household heads, and those involved in village work borrowed larger sums. Abdalla and Ebiadalla (2012) found that access of farmer to the formal credit institution is positively influenced by family size, experience of the household head in credit use, ownership of adequate collateral, and participation of the household head in training/extension activities. They also found that age of household head, distance travelled by farmer to the lending institution and farm size influence credit access.

Meanwhile, empirical work by Arene (1993) revealed income, farm size, age of farmers, farming experience and level of education of farmers contributed positively to the credit worthiness of farmers. Oladeebo and Oladeebo (2008) examined the determinants of loan repayment among smallholder farmers in Ogbomoso Agricultural Zone, Nigeria. Results from multiple regression analysis showed that amount of loan obtained by farmers, years of farming experience with credit and level of education were major factors that positively and significantly influenced loan repayment. Eze and Ibekwe (2007) examined the determinants of loan repayment under the indigenous financial system in Southeast Nigeria. Empirical results from multiple regression analysis revealed amount of loan received, age of beneficiary, household size, years of formal education and occupation as important predictors of loan repayment under the system.

Mashatola and Darroch (2003) analyzed the factors affecting the loan status and repayment scheme of sugarcane farmers who received graduated mortgage loan in Kwazulu-Natal, South Africa. Results identified farm size (proxied by annual gross turnover), access to off-farm income, and average annual gross turnover relative to loan size as criteria in selecting potential farmers for such scheme as they provided additional liquidity to fund future operations and debt repayment.

Okorie (1986) examined the major determinants of agricultural smallholder loan repayment in Ondo State, Nigeria. Results identified the nature and timeliness of loan disbursement, the number of supervisory visits by credit officers, profitability of the enterprise on which the loan funds were invested as significant factors that stimulate loan repayment. Kohansal and Mansoori (2009) investigated the factors affecting loan repayment performance of farmers in Khorasan- Razavi Province of Iran. Results from a logistic model showed that loan interest rate was the most important factor affecting repayment of agricultural loans. Farming experience, and total application cost were the next factors respectively.

Bassem (2008) examined the factors vulnerable to affect the repayment performance of group lending in Tunisia. Empirical results from a logistic regression estimation showed that the repayment is influenced positively by the internal rules of conduct, the same business, and the knowledge of the other members of the group before its formation, the peer pressure, the self-selection, the sex, the education and the non financial services. However, the homogeneity, and the marital status had a negative influence on repayment.

\section{Study Area}

\section{Methodology}

Ebonyi State is the study area. Ebonyi state is located in the South East geographical zone of Nigeria. The state was created on $1^{\text {st }}$ October, 1996 out of the former Abia and Enugu States. Ebonyi State has an estimated land area of about $5,935 \mathrm{~km}^{2}$ and a population of $2.17 \mathrm{~m}$ people (NPC, 2006). The state lies approximately between latitudes $7^{0} 30^{1} \mathrm{~N}$ of the equator and longitudes $5^{0} 40^{1}$ and $6^{0} 45^{1} \mathrm{E}$ of the Greenwich Meridian. The climate of the state follows tropical pattern with long wet season commencing from April and ending in October then followed by dry season from November to March. The mean annual temperature is about $80^{\circ} \mathrm{F}$ and the mean annual rainfall varies between $1700 \mathrm{~mm}$ to $2500 \mathrm{~mm}$ (Eze and Idike, 1997). Politically, the state is delineated into thirteen (13) local government areas with three (3) agricultural zones.

\section{Sampling Procedure}

The sampling frame for the study included all the small scale rice farmers that benefited from agricultural credit from three formal lending agencies from 2010-2014. A multistage simple random sampling technique was adopted to select respondents for the study.

\section{Data Collection}

Data required for this study were collected mainly from primary sources. Data collected from amount of loan sourced and obtained from different formal lending agencies such as Microfinance Bank (MFB), Bank of Agriculture (BOA) and Commercial Bank (CB). Also included were factors that influence farmers demand for credit and factors that constrain farmers access to credit such as security, farming experience etc. Data were also collected from financial lending agencies on the repayment performance of the farmers and other information to incorporate into identified factor perceived by farmers to gain broad knowledge of the factors that influence loan acquisition and repayment. 


\section{Data Analysis}

Descriptive and inferential statistics were used accordingly for the analysis of the data collected. Objective i was realized using descriptive statistics like frequency, percentage etc. Objective ii was realized using multiple regression. Objective iii was realized using proportional percentage and objective iv was realized using logit regression model.

\section{Model Specification}

Multiple Regression Model:

$\mathrm{Y}=\mathrm{f}\left(\mathrm{X}_{1}, \mathrm{X}_{2}, \mathrm{X}_{3}, \mathrm{X}_{4}, \mathrm{X}_{5}, \mathrm{X}_{6}, \mathrm{X}_{7}, \mathrm{X}_{8}, \mathrm{X}_{9}\right)+\mathrm{e}_{\mathrm{i}}$

Where

$\mathrm{Y}=$ Amount of loan acquired $(\#)$

$\mathrm{X}_{1}=$ Farm size $(\mathrm{Ha})$

$\mathrm{X}_{2}=$ Cost of farm inputs $(\#)$

$\mathrm{X}_{3}=$ Farmers' income $(\#)$

$\mathrm{X}_{4}=$ Farmers' age ( years)

$\mathrm{X}_{5}=$ Use of improved technology ( dummy)

$\mathrm{X}_{6}=$ Interest charge $(\#)$

$\mathrm{X}_{7}=$ Educational level $($ years )

$\mathrm{X}_{8}=$ Transaction cost $(\#)$

$\mathrm{X}_{9}=$ Farming experience $($ years $)$

$\mathrm{e}_{\mathrm{i}}=$ error term.

\section{Results And Discussion}

Table 4.1 Percentage Distribution of Quantum (Amount Sourced) of Loan, Number of Beneficiaries and Average Loan per Beneficiary from Formal Lending Agencies.

\begin{tabular}{|l|l|l|l|l|}
\hline Loan Sources & Loan Volume (N) & $\begin{array}{l}\text { Number of } \\
\text { Beneficiaries }\end{array}$ & $\begin{array}{l}\text { Av. Loan per } \\
\text { Beneficiary (N) }\end{array}$ & $\begin{array}{l}\text { Percentage of Total } \\
\text { Loan Vol. }(\%)\end{array}$ \\
\hline Microfinance Bank (MFB) & $7,956,765.67$ & 40 & $198,919.14$ & 38 \\
\hline Bank of Agriculture (BOA) & $9,548,970.50$ & 56 & $170,517.33$ & 46 \\
\hline Commercial Bank (CB & $3,394,263.80$ & 24 & $141,427.66$ & 16 \\
\hline Total & $20,900.000 .00$ & 120 & $170,173.40$ & 100 \\
\hline
\end{tabular}

Source: Field Survey, 2015.

Table 4.6 shows that $33 \%$ of the respondents sourced an average amount of \# 198,919.14 from Microfinance Bank, 47\% of them sourced on average a sum of \# 170,517.33 from Bank of Agriculture while the remaining $20 \%$ of the respondents sourced on average a sum of \#141,427.66 from Commercial Bank. Therefore, each of the respondents sourced on average a total amount of \# 170,173.40 from various formal lending agencies.

\section{Quantum of Loan Acquired}

Table 4.2 Percentage Distribution of the Amount of Loan (Acquired) or Procured, Number of Beneficiaries and Average Loan per Beneficiary form Formal Lending Agencies.

\begin{tabular}{|c|c|c|c|c|}
\hline Loan Sources & $\begin{array}{l}\text { Amount of loan Acquired } \\
\text { or Procured }\end{array}$ & $\begin{array}{l}\text { Number } \\
\text { Beneficiaries }\end{array}$ & $\begin{array}{l}\text { Av. Loan per } \\
\text { Beneficiary ( }(\mathbb{N})\end{array}$ & $\begin{array}{l}\text { Percentage of Total } \\
\text { Loan Vol. }(\%)\end{array}$ \\
\hline Bank of Agriculture (BOA) & $7,225,430.50$ & 56 & $129,025.55$ & 46 \\
\hline Total & $15,675,000.00$ & 120 & $128,557.40$ & 100 \\
\hline
\end{tabular}

Source: Field survey, 2015.

Table 4.7 show that $33 \%$ of the respondents acquired or procured on average a sum of $\$ 143,128.14$ from Microfinance Bank, 47\% of the respondents procured on average a sum of $\$ 129,025.55$ from Bank of Agriculture while the remaining $20 \%$ of them procured on average a sum of $\$ 113,518.50$ from Commercial Bank. A total average amount of $\$ 128,557.40$ was successfully procured by each of the respondents from various formal lending agencies. This implies that each of the respondents was able to procure on average $75 \%$ only of the total amount sourced from these formal lending agencies.

\section{Determinants of Successful Loan Acquisition from Formal Financial Institutions}

Various formal lending agencies consider different factors before disbursing loan to beneficiaries. All these factors were anchored on the principle of averting the risk of losing their worth to loan defaulters. As such, variables obtained from various lending institutions were incorporated into other factors perceived by the farmers. A multiple regression model was used to analyze variables in relation to loan acquisition from formal lending agencies. 
Table 4.3 Result of Multiple Regression Analysis on Determinants of Loan Acquisition from Formal Financial Institutions by Small Scale Rice Farmers.

$\begin{array}{lll}\text { Adjusted } & \mathrm{R}^{2} & 0.800 \\ \text { F-ratio } & & 60.541 \\ * & = & 1 \% \text { level of significant } \\ * * \quad= & 5 \% \text { level of significant }\end{array}$

\begin{tabular}{|l|l|l|l|}
\hline Variable & Coefficient & Std error & t-value \\
\hline Constant & -1414398.494 & 113621.516 & -12.448 \\
\hline Farm size & 21448.293 & 10216.096 & $2.099^{* *}$ \\
\hline Cost of farm inputs & 68293.723 & 15945.894 & $4.283^{* *}$ \\
\hline Farmers' income & -966.558 & 15449.589 & -.063 \\
\hline Farmer's age & -11442.623 & 24054.743 & -.476 \\
\hline Use of improved tech. & 422.603 & 964.120 & 0.438 \\
\hline Interest charge & -78011.874 & 12317.573 & $-6.333^{*}$ \\
\hline Educational level & 2824.252 & 8561.018 & .330 \\
\hline Transaction cost & -2485.906 & 3201.075 & -.777 \\
\hline Farming experience & 10538.007 & 9561.378 & 1.102 \\
\hline $\mathrm{R}^{2}$ & 0.814 & & \\
\hline
\end{tabular}

Source: Field Survey, 2015

Form the table, the $\mathrm{R}^{2}$ of 0.80 shows that $80 \%$ of the variation of the dependent variable (amount of loan acquired) is explained by the variables included in the model. The study shows that farm size and cost of inputs were both positive and significant. This implies that the greater the quantity of these variables, the higher the amount of loan the farmer will be willing to acquire from lending agencies. This study is consistent with the findings of Ukoha et al (2011) who found these variables to be positive. However, interest charge was negative and significant at $1 \%$. This indicates that the variable has inverse relationship with amount of loan acquired; implying that increase in the interest charge on loan will lead to the decrease in the amount of loan acquired. This study confirms the findings of Mba (2009).

\section{Repayment Rate Among Rice Farmers Beneficiaries}

Table 4.4 Determination of the Repayment Rate by the Beneficiaries from the Formal Lending Agencies.

\begin{tabular}{|l|l|l|l|l|l|l|l|}
\hline $\begin{array}{l}\text { Lending Agencies } \\
\text { (Sources) }\end{array}$ & $\begin{array}{l}\text { Amount } \\
\text { Acquired } \\
(\mathrm{N})\end{array}$ & $\begin{array}{l}\text { Interest } \\
\text { Payment } \\
(\mathrm{N})\end{array}$ & $\begin{array}{l}\text { Total Amount } \\
\text { Repayable } \\
(\mathrm{N})\end{array}$ & $\begin{array}{l}\text { Amount } \\
\text { Repaid (N) }\end{array}$ & $\begin{array}{l}\text { Outstanding } \\
\text { Balance }\end{array}$ & $\begin{array}{l}\text { Repayment } \\
\text { Rate (\%) }\end{array}$ & $\begin{array}{l}\text { Default } \\
\text { Rate }(\%)\end{array}$ \\
\hline Microfinance bank & $5,725125.70$ & $2,790,998.80$ & $8,516,124.50$ & $\begin{array}{l}6,387,093.3 \\
8\end{array}$ & $2,129,031.12$ & 75 & 25 \\
\hline Bank of agriculture & $7,225430.50$ & $3,522397.39$ & $10,747,827.89$ & $\begin{array}{l}7,845,914.3 \\
6\end{array}$ & $2,901,913.53$ & 73 & 27 \\
\hline Commercial bank & $2,724443.80$ & $1,428166.38$ & $4,052,610.18$ & $\begin{array}{l}2,796,301.0 \\
2\end{array}$ & $1,256,309.16$ & 69 & 31 \\
\hline Total & $15,675000.00$ & $7,641562.57$ & $23,316,562.57$ & $\begin{array}{l}17,029,306 . \\
76\end{array}$ & $6,287,253.81$ & & \\
\hline
\end{tabular}

Source: Field Survey, 2015.

Table 4.9 shows that out of \#8,516,124.50 repayable to Microfinance Bank by loan beneficiaries, only $\# 6,387,093$ (75\%) was repaid at when due. A sum of \#10, 747,827.89 repayable to Bank of Agriculture, only $\# 7,847,914.36$ (73\%) was repaid while \#4,052,610.18 repayable to Commercial Bank, only \#2,796,301.02 (69\%) was repaid by the loan beneficiaries as at when due. This implies that some of the loan beneficiaries delayed loan repayment. This study affirms the findings of Ike and Abojei (2009) that loan repayment rate is influenced by several factors.

Factors Affecting Loan Repayment Performance of Rice Farmers

Table 4.10 Logit Estimates of Factors Affecting Loan Repayment.

\begin{tabular}{|l|l|l|l|}
\hline Variable & Coefficient & $\begin{array}{l}\text { Aggregate Weighted } \\
\text { Elasticity }\end{array}$ & Marginal Effect \\
\hline Age & $-0.024(-1.304)$ & -0.5806 & -0.006 \\
\hline Farm size & $-0.0274(-1.447)$ & -0.098 & -0.007 \\
\hline Farming experience & $0.0562(1.98)^{*}$ & 0.574 & 0.008 \\
\hline Income & $0.0562(4.234)^{* *}$ & 0.574 & 0.008 \\
\hline Interest charge & $-0.2180(4.452)^{* *}$ & -0.765 & -0.037 \\
\hline Time lag & $-0.0064(-0.324)$ & -0.009 & -0.003 \\
\hline Loan application cost & $-0.0363(-2.478)^{* *}$ & -0.413 & -0.009 \\
\hline Loan size & $0.1082(2.497)^{* *}$ & 0.346 & 0.033 \\
\hline Security & $0.0911(3.541)^{* *}$ & 0.275 & 0.026 \\
\hline Number of installments & -0.0121() & -0.218 & -0.004 \\
\hline
\end{tabular}




\begin{tabular}{|l|l|l|l|}
\hline D1 & $-0.06723(-1.582)$ & -0.142 & -0.134 \\
\hline D2 & $0.2851(0.751)$ & 0.068 & 0.068 \\
\hline McFadden R ${ }^{2}$ & 0.26430 & F-36.319 & \\
\hline
\end{tabular}

Figures in parenthesis are t-values

NB. $* *, *$ refer to significant at $5 \%$ and $10 \%$ respectively.

Source: Computed from Field Survey, 2015.

Variables

Farming experience: It's co-efficient is 0.562 while it t-value is 1.986 which is significant at $10 \%$ probability level. This implies that there is a high probability of more experienced farmers to repay loan obtained from lending agencies. This is not far from the fact that when farmers become more knowledgeable in farming practices, their level of income will increase and hence their loan repayment performance. Oladeebo and Oladeebo (2008) supported that as farmers get more practical knowledge in farming activities, the probability of repayment loan increases.

Farmers' income. This has a co-efficient of 0.3710 and t-value of 4.234 which is significant at five parent probability level. This means that income is one of the major factors that is critical in repayment performance. It implies that as farmers income increases the probability of repaying loan increases.

Interest charge: Interest charge has a coefficient of -0.2180 and a t-value of 4.452 which is significant at five percent probability level. This means that high interest rate entails high price to be paid for the use of credit. It complicates the problem of repayment because it increases the amount the farmer ought to repay. This study is in contradiction with the finding of Afolabi (2011) who found interest rate to be positive.

Loan size: Its coefficient is 0.1082 and has a t-value of 2.497 which is significant at five percent probability level. This means that the volume of loan granted to a farmer enables him to adopt agricultural innovations which can translate to increase in the level of income and hence high level of repayment (Afolabi 2011; Mahammad and Hooman 2009).

Security: This has a coefficient of 0.0911 and a t-value of 3.541 which is significant at five percent probability level. This implies that the higher the security used in loan acquisition, the higher the repayment performance of the recipients.

\section{Conclusion}

Result of the socio-economic characteristics of the farmers revealed that majority of the loanbeneficiaries is within the active productive age bracket which is instrumental to their ability of procuring loan from financial institutions. The financial institutions are the backbone of the small scale farmers when compared to informal sources due to loan adequacy and low interest charge. More importantly, credit is required by small holder farmers to achieve total transformation from the level of subsistence orientation to market orientation. This is based on the result that credit determines farmers' accessibility to other resources.

\section{Recommendations}

From the findings of the study, the following recommendations were made:

i. The financial institutions should dedicate a special credit to farmers that will be relatively flexible in its procedure to enable farmers access adequate amount that will be enough to acquire agricultural equipments and make meaningful investments.

ii. Price and non price variables that significantly influence loan repayment should be sought for by financial institutions before granting loans to small scale farmers so as to reduce the incidence of loan delinquencies and default.

iii. Repayment plans of financial institutions should be reviewed to make provision for the gestation period of crops and sales period to curtail high incidence of loan default.

Iv. Income generated by farmers who have access to credit should be used by the credit providers to assess the performance of farmers who utilized resources properly for provision of more credit

\section{References}

[1]. Abdalla, E. M. \& Ebaidalla, E. M. (2012). Determinants of small farmer's access to formal credit institutions in Kassala state, East Sudan. University of Kassala Journal, First Issue, April 2012.

[2]. Adegbite, S. A., Momoh, S. \& A. Alade (2007). Determinants of Informal Savings Mobilization among Farmers in Ogun State, Nigeria. Journal of Sustainable Development 4(1\&2) Amstys Book and Co., Abeokuta.

[3]. Amjad, S. \& Hasnu, SAF (2007). Smallholders' access to rural credit: Evidence from Pakistan. The Labore Journal of economics. Vol. 12(2): 1-25

[4]. Arene, C. J. (1993) An analysis of loan repayment potentials of smallholder soyabean group farmers in Nigeria. Quarterly Journal of International Agriculture, 1993, 32(1): 160-169.

[5]. Bassem B. S.(2008) Determinants of successful group loan repayment: An application to Tunisia. Journal of Sustainable Development in Africa, 2008, vol.10, No. 2. 
[6]. Central Bank of Nigeria (2007). Agricultural Credit Guarantee Scheme Fund of Nigeria (ACGSF): An Impact Assessment Study conducted by Centre for Resource Analysis and Management for the Governing Board of the ACGSF, Abuja CBN.

[7]. Central Bank of Nigeria (CBN) (2002). "Baseline Study for Microfinance Institutions in Nigeria. CBN Publications, Lagos. Economic Development Institute (EDI) (1993). Financial System and Development in Africa, EDI Series 1993.

[8]. Doan, T., Gibson, J. \& Holmes, M. (2010). What determines credit participation and credit constraints of the poor in peri-urban areas, Vietnam? MPRA Paper No. 27509.

[9]. Duy, V. Q. (2011). Factors affecting on Access to formal credit of households in the Mekong delta, Vietnam. School of Economics and Business Administration, Can Tho University, Vietnam

[10]. Duy, V. Q. (2012). Determinants of household access to formal credit in the rural areas of the Mekong Delta, Vietnam. MPRA Paper No. 38202

[11]. Eboh, E. G. (1998). Social and Economic Research; Principles and Methods. Academic Publication and Development Resources Ltd, Lagos.

[12]. Eze, C. C. \& U. C. Ibekwe (2007) Determinants of loan repayment under the Indigenous financial system in Southeast, Nigeria. The Social Sciences, 2007, 2(1): 116-120]

[13]. Eze, O. C. \& A.A. Idike (1997). Ebonyi State:” The People's Vision of Development” . A Report by a National UNDP Sponsored Survey. Pp.3-7

[14]. Ezeugo, C. (1998). Improving Institutional Financial Private Agriculture in Nigeria: The Role of Central Bank of Nigeria pp.234249.

[15]. Food and Agricultural Organization (FAO) (1997). Review of the State of World Agriculture. FAO Fisheries Circular, 887 (Rev.1): 97-99.

[16]. Kohansal M. R. \& H. Mansoori (2009) Factors affecting loan repayment performance of farmers in Kharasan-Razavi province of Iran. A paper presented in a conference on International Research on Food Security. Natural Resource Management and Rural Development, University of Hamburg, October6-8, 2009.

[17]. Komicha, H. H. (2007). Farm Household Economic Behaviour in Imperfect Financial Markets: Empirical Evidence and Policy Implications on Saving, Credit and Production Efficiency in Southeastern Ethiopia. Doctoral Thesis, Swedish University of Agricultural Sciences, Uppsala.

[18]. Lawal, J. O. \& T. R. Shittu (2006). Resource Availability and Cocoa Farming in Kwara State. Being a Paper presented at Science Association of Nigeria at Tai Solarin University of Education, Ijebu-Ode, Ogun State

[19]. Mashatola, M. C. \& M. A. G. Darroch (2003) Factors affecting the loan status of sugarcane farmers using a graduated mortgage loan repayment scheme in KwaZulu-Natal. Agricultural Economics Association of South Africa, 2003, 42(4).

[20]. Nto, P. O. \& J. A. Mbanasor (2008). Analysis of Credit Repayment among Arable Crops Farmers under Rural Banking Scheme in Abia State, Nigeria. Inter. J. Agric. Rural Dev. 11(1)

[21]. Nwagbo, E. C. (1991) “Credit Access and Use in Agriculture” Paper delivered on Agricultural Finance: Problems and Prospects. Agric. Exhibition, University of Nigeria, Nsukka.

[22]. Oboh, V. U. \& Ekpebu, I. D. (2010). Determinants of formal agricultural credit allocation to the farm sector by arable crop farmers in Benue State, Nigeria. African Journal of Agricultural Research, Vol. 6(1):181-185

[23]. Okorie, A.(1986) Major determinants of agricultural smallholder loan repayment in a developing economy: Empirical evidence from Ondo State Nigeria. Agric. Administration, 1986, 21(1): 223-234.

[24]. Okorie, A. (1998). The Agricultural Credit Guarantee Scheme Fund and Credit Administration in Nigeria: Problems and Prospects. In M. O. Ijere and A. Okorie (Eds.) Readings in Agricultural Finance. Longman Publisher, Ikeja, Nigeria. 38-40

[25]. Okurut, F. N. (2001). Access to Credit by the Poor in South Africa: Evidence from Household Survey Data 1995 and 2000. Stellenbosch Economic Working Papers: 13/06।

[26]. Oladeebo, O. E. (2008). Social Economic Factors Influencing Loan Repayment among Small Scale Farmers in Ogbomoso Agricultural Zone of Oyo State, Nigeria. Full Professional Diploma Project (Unpublished) Department of Management Science, Ladoke Akintola University of Technology, Ogbomoso.

[27]. Oladeebo, J. O. \& O. E. Oladeebo (2008) Determinants of loan repayment among smallholder farmers in Ogbomoso agricultural zone of Oyo State, Nigeria. Journal of Social Sciences, 2008,17(1): 59-62.

[28]. Olaitan, M. A. (2005). Finance for Small and Medium Enterprises: Nigeria's Agricultural Credit Guarantee Scheme Fund. Journal of International Farm Management. 13(2). www.infmaonline.org.

[29]. Olomola, A. S. (1990). Loan Transaction Cost and Repayment Performance among Small Scale Farmers in Ondo State, Nigeria. Unpublished Ph.D. Thesis in the Department of Agricultural Economics, University of Ibadan, Nigeria.

[30]. Tanko, N. M. (1994). Contribution of Rural Women to Agricultural Planning and Economic Development in Nigeria, In: Ikpi, A. E. Olayemi, J. K. (ed) Winrock International for Agricutural Development.

[31]. Ukoha, H., J. S. Orebiyi, P. C. Obasi, N. N. Oguoma, D. Ohajianya, U. C. Ibekwe \& I. I. Ukoha (2011). Determinants of Loan Acquisition from the Financial Institutions by Small Scale Farmers in Ohafia Agricultural Zone of Abia State, South East Nigeria. 